\title{
Variation in phosphorus efficiency among 73 bread and durum wheat genotypes grown in a phosphorus-deficient calcareous soil
}

\author{
Levent Ozturk ${ }^{1}$, Selim Eker ${ }^{1}$, Bulent Torun ${ }^{1}$ \& Ismail Cakmak ${ }^{2,3}$ \\ ${ }^{1}$ Department of Soil Science, Faculty of Agriculture, Cukurova University, Adana, Turkey. ${ }^{2}$ Faculty of Engineering \\ and Natural Sciences, Sabanci University, Istanbul, Turkey. ${ }^{3}$ Corresponding author*
}

Received 19 February 2004. Accepted in revised form 27 May 2004

Key words: genotypic variation, nutrient efficiency, phosphorus, wheat

\begin{abstract}
A greenhouse experiment was carried out to study the severity of phosphorus (P) deficiency symptoms on leaves, shoot dry matter production, and shoot concentration and content (the total amount per shoot) of $\mathrm{P}$ in 39 bread wheat (Triticum aestivum L.) and 34 durum wheat (Triticum durum L.) genotypes grown in a severely P-deficient calcareous soil with low (20 mg P kg-1 soil) and adequate ( $80 \mathrm{mg} \mathrm{P} \mathrm{kg}^{-1}$ soil) $\mathrm{P}$ supply for 39 days. As the seed $\mathrm{P}$ concentration or content can affect plant performance under P-deficient conditions, the seeds of the genotypes used in the present study were also analyzed for P concentration. Phosphorus efficiency (relative shoot growth) of genotypes, calculated by the ratio of shoot dry matter production under low $\mathrm{P}$ to that under adequate $\mathrm{P}$ supply, significantly differed among the genotypes, and varied between $46.7 \%$ and $78.6 \%$. Phosphorus efficiency ranged from $51 \%$ to $71 \%$ with an average of $61 \%$ for bread and from $47 \%$ to $79 \%$ with an average of $66 \%$ for durum wheat genotypes. There was no correlation between P efficiency ratio and P concentration of plants $\left(R^{2}=0.0001\right)$, but $\mathrm{P}$ efficiency of all bread and durum wheat genotypes showed a very significant correlation with the $\mathrm{P}$ content (the total amount of $\mathrm{P}$ per shoot) $\left(R^{2}=0.333^{* * *}\right)$. The relationship between the $\mathrm{P}$ efficiency and total amount of $\mathrm{P}$ per shoot was much more significant in bread $\left(R^{2}=0.341^{* * *}\right)$ than in durum wheat $\left(R^{2}=0.135^{*}\right)$. Like shoot $\mathrm{P}$ concentrations, also severity of visible leaf symptoms of $\mathrm{P}$ deficiency on older leaves, including leaf chlorosis and necrosis, did not correlate with P efficiency. In most cases, genotypes showing higher P efficiency had higher absolute shoot dry weight under P deficient conditions. Under P deficient conditions, the absolute shoot dry weight very significantly correlated with shoot $\mathrm{P}$ content $\left(R^{2}=0.665^{* * *}\right)$, but the correlation between the absolute shoot dry weight and shoot $\mathrm{P}$ concentration tended to be negative. There was also variation in native seed $\mathrm{P}$ reserve of the genotypes, but this variation had no influence on the P efficiency. The results indicate that the total amount of $\mathrm{P}$ per shoot and shoot dry matter production at low $\mathrm{P}$ supply are most reliable parameters in ranking genotypes for P efficiency at early growth stage. In wheat germplasm tested in the present study, several wheat genotypes are available showing both very high $\mathrm{P}$ efficiency and very high shoot content and concentration of $\mathrm{P}$ suggesting that $\mathrm{P}$ acquisition ability should be most important mechanism for high $\mathrm{P}$ efficiency in such genotypes. On the other hand, there are also genotypes in the germplasm having more or less same $\mathrm{P}$ concentration or $\mathrm{P}$ content in shoot but differing substantially in $\mathrm{P}$ efficiency, indicating importance of $\mathrm{P}$ utilization at cellular level in $\mathrm{P}$ efficiency. All these results suggest that $P$ efficiency mechanisms can be different from one genotype to other within a given plant species.
\end{abstract}

\section{Introduction}

Phosphorus deficiency is a common mineral nutritional problem in both calcareous soils and acidic soils

\footnotetext{
* FAX No: +90-216-483 9550.

E-mail: cakmak@sabanciuniv.edu
}

due to formation of poorly soluble $\mathrm{P}$ complexes with calcium in alkaline and aluminum and iron in acidic soils. It is estimated that $\mathrm{P}$ availability to plant roots is limited in nearly $67 \%$ of the cultivated soils, causing an important constraint to crop production (Batjes, 1997). In Turkey, where almost all soils are alka- 
line, $58 \%$ of cultivated soils contain low amounts of plant available P (Eyupoglu, 1999). Most of the $\mathrm{P}$ applied to soils to meet $\mathrm{P}$ demand of plants is converted into unavailable forms of $\mathrm{P}$ that cannot be easily used and taken up by plant roots. Development of plant genotypes (e.g., 'P-efficient' genotypes) with greater ability to grow and yield under P-deficient soil conditions is, therefore, an important goal in plant breeding (Rengel, 1999; Hash et al., 2002; Wissuwa et al., 2002; Yan et al., 2004). Release of P-efficient genotypes in both high- and low-input production systems would reduce the production costs associated with $\mathrm{P}$ fertilizer applications, minimize environmental pollution and contribute to maintenance of world $\mathrm{P}$ resources globally (Cakmak, 2002; Vance et al., 2003).

Plant species and genotypes of a given species develop diverse adaptive responses when they suffer from $\mathrm{P}$ deficiency stress. To maintain improved growth under P-deficient conditions plants develop two major mechanisms: (i) P acquisition (root morphology, root exudation and $\mathrm{P}$ uptake mechanisms) and (ii) $\mathrm{P}$ utilization (internal mechanisms associated with better use of absorbed P at cellular level) (Marschner, 1995; Rengel, 1999; Raghothama, 1999; Bates and Lynch, 2001; Vance et al., 2003). It is well-documented that plant genotypes differ greatly in adaptive mechanisms to $\mathrm{P}$ deficiency stress. Despite huge amount of available studies there is, however, no general mechanism that can explain the nature of high $\mathrm{P}$ efficiency. Phosphorus efficiency mechanisms, either at level of $\mathrm{P}$ acquisition from soil or efficient use of $\mathrm{P}$ in tissue, are often studied by using a limited number of genotypes as in the case of wheat (Horst et al., 1993; Gahoonia et al., 1999; Fageria and Baligar, 1999; Manske et al., 2002; Yao et al., 2001). To achieve a sufficient and useful genetic variation for $\mathrm{P}$ efficiency, a large number of genotypes is needed for screening. Only a few studies have included a substantial number of wheat genotypes to study the extent of genetic variability for P efficiency and to characterize mechanisms involved in expression of P efficiency (Batten, 1986; Jones et al., 1989; Manske et al., 2000; Osborne and Rengel, 2002a, b, c). In these studies genotypes have been tested which are grown predominantly in Australia and at CIMMYT. In the present study a set of 39 bread and 34 durum wheat genotypes (obtained from breeding programs realized on calcareous soils by Cukurova University, Adana and the Turkish Ministry of Agriculture) was used to study (i) the extent of genetic variability in $\mathrm{P}$ efficiency (i.e. relative shoot growth) of wheat and (ii) a suitable screening parameter for high $\mathrm{P}$ efficiency at early growth stage. For this purpose plants were tested for the shoot dry matter production, $\mathrm{P}$ concentration and content (total amount of P) in shoot and severity of P deficiency symptoms on leaves when grown in a P-deficient calcareous soil with and without adequate $\mathrm{P}$ supply. Also $\mathrm{P}$ concentrations of seeds were measured to evaluate the possible contribution of seed $\mathrm{P}$ reserve in $\mathrm{P}$ efficiency of wheat.

\section{Materials and methods}

A total of 39 bread wheat and 34 durum wheat genotypes were grown under greenhouse conditions in plastic pots containing $1650 \mathrm{~g}$ soil. The soil used was deficient in plant available $\mathrm{P}$ and obtained from a P-deficient region in Central Anatolia. Concentration of $\mathrm{NaHCO}_{3}$-extractable $\mathrm{P}$ in the soil $(0-30 \mathrm{~cm}$ depth) was $3.1 \mathrm{mg} \mathrm{kg}^{-1}$ as measured by the method of Olsen et al. (1954). The soil characteristics were: pH 8.04 (1:1 $\mathrm{H}_{2} \mathrm{O}:$ soil), $\mathrm{CaCO}_{3} 149 \mathrm{~g} \mathrm{~kg}^{-1}$, organic matter $7 \mathrm{~g} \mathrm{~kg}^{-1}$ and soil texture was clay. About 15 seeds were sown in each pot, and after emergence the seedlings were thinned to 10 per pot at the 2leaf stage. Two levels of $\mathrm{P}$ were applied (low P: $20 \mathrm{mg} \mathrm{kg}^{-1}$ soil and adequate P: $80 \mathrm{mg} \mathrm{kg}^{-1}$ soil) in the form of $\mathrm{CaH}_{4} \mathrm{O}_{8} \mathrm{P}_{2} \mathrm{H}_{2} \mathrm{O}$, together with a basal treatment of $200 \mathrm{mg} \mathrm{N} \mathrm{kg}^{-1}$ soil as $\mathrm{Ca}\left(\mathrm{NO}_{3}\right)_{2} \cdot 4 \mathrm{H}_{2} \mathrm{O}$ and $\mathrm{KNO}_{3}$, and $50 \mathrm{mg} \mathrm{K} \mathrm{kg}{ }^{-1}$ soil as $\mathrm{KNO}_{3}$. All nutrients were mixed thoroughly with soil before potting. The treatments were performed in triplicate according to completely randomized design in a greenhouse. Pots were watered daily with deionized water.

Before harvesting, plants grown with low $\mathrm{P}$ treatment were scored for the severity of $\mathrm{P}$ deficiency symptoms, i.e., progressive desiccation from tips to bottom of the oldest leaves. The severity of symptoms was assessed by giving a score from 1 (very severe symptoms) to 5 (very slight or no symptom). At 39 days after planting, shoots were harvested, dried at $70{ }^{\circ} \mathrm{C}$, ground and ashed at $550{ }^{\circ} \mathrm{C}$ for determination of $\mathrm{P}$ concentration in the whole shoot. The ashed samples were then dissolved in $3.3 \% \mathrm{HCl}$ and analyzed for P by using the method of Barton (1948). Concentration of seed $\mathrm{P}$ was measured by inductively coupled plasma atomic emission spectroscopy (ICP-AES, Jobin Yvon, France) at $214.914 \mathrm{~nm}$ emission wavelength. The $\mathrm{P}$ efficiency ratio (relative shoot growth) was calculated as the ratio of shoot dry matter production under low to that under adequate $\mathrm{P}$ supply. 
Data were statistically analyzed by ANOVA (MSTATC software) and means compared using least significant differences (LSD). Regressions and curve fittings were performed with MS Excel software employing the Statistical Analysis ToolPak. The asterisks shown in figures as ${ }^{*},{ }^{* *}$ and ${ }^{* * *}$ indicates significance at $\alpha=0.05,0.01$ and 0.001 , respectively.

\section{Results}

As expected, there were no visual symptoms of $\mathrm{P}$ deficiency in genotypes supplied with adequate $P$, whereas in the low $\mathrm{P}$ treatment, development of dark-green color in leaves and reduction in shoot elongation and leaf size were the first visual symptoms of $\mathrm{P}$ deficiency in most genotypes. As the $\mathrm{P}$ deficiency stress progressed, the oldest leaves became chlorotic and showed desiccation started from the leaf tips. Severity and development time of these leaf symptoms greatly differed among wheat genotypes (Tables 1 and 2). Low $\mathrm{P}$ supply significantly decreased shoot growth of all genotypes. At low P supply shoot dry weight per plant changed between $345 \mathrm{mg}$ (cv. Aday 98-2) to $629 \mathrm{mg}$ (cv. Ka 'S'/NAC) in bread wheat (Table 1) and $442 \mathrm{mg}$ (cv. Cakmak) to $688 \mathrm{mg}$ (cv. Jabiru-4) in durum wheat (Table 2). On average, the durum wheat genotypes produced a greater amount of dry matter than the bread wheat genotypes both under low and adequate supply of $\mathrm{P}$. The $\mathrm{P}$ efficiency ratio (relative shoot growth) showed marked variation among genotypes (Tables 1 and 2). The genotypic variation in $\mathrm{P}$ efficiency ratio was larger in durum than bread wheat. In the case of bread wheat $\mathrm{P}$ efficiency ratio ranged from 50.6 (cv. Bow 'S'/Crow 'S'-2) to 71.4 (cv. Ka 'S'/NAC) with a mean value of 61.2 (Table 1), while in durum wheat the variation was between 46.7 (cv. Gediz-75) and 78.6 (cv. Aw 12/Bit) with a mean value of 65.9 (Table 2). The bread wheat genotypes $\mathrm{Ka}$ 'S'/NAC, PFAU/Vee and Kayson//Pvn 'S' (Table 1) and the durum wheat genotypes Aw12/Bit, Diyarbakir-81 and Ceylan-95 (Table 2) showed greater P efficiency and produced higher yield than the average yield at low $\mathrm{P}$ supply.

Low $\mathrm{P}$ supply resulted in a significant reduction (up to 50\%) in shoot $\mathrm{P}$ concentration of genotypes (Tables 3 and 4). Under low P supply, both durum and bread wheat genotypes showed significant variation in shoot $\mathrm{P}$ concentration. At adequate $\mathrm{P}$ supply shoot $\mathrm{P}$ concentrations were within the sufficiency range of 2-4 mg g ${ }^{-1}$ (Reuters and Robinson, 1997). In the case of total amount (content) of $\mathrm{P}$ per shoot, the genotypes differed significantly at low P supply (Tables 3 and 4). Despite significant variation in shoot $P$ concentration among wheat genotypes, the correlation between shoot $\mathrm{P}$ concentration and the $\mathrm{P}$ efficiency ratio was zero $\left(R^{2}=0.0001\right)$ for all durum and bread wheat genotypes (Figure 1). Even in the case of durum wheat genotypes the correlation between $\mathrm{P}$ efficiency and shoot $\mathrm{P}$ concentration tended to be negative. In contrast to $\mathrm{P}$ concentration, the total amount of $\mathrm{P}$ ( $\mathrm{P}$ content) per shoot showed a very significant correlation with $\mathrm{P}$ efficiency ratio $\left(R^{2}=0.333^{* * *}\right)$ (Figure 1). Interestingly, the relationship between $\mathrm{P}$ efficiency ratio and shoot $\mathrm{P}$ content was much more significant in bread $\left(R^{2}=0.341^{* * *}\right)$ than in durum wheat $\left(R^{2}=0.135^{*}\right)$. This may indicate a greater role of $\mathrm{P}$ uptake in expression of high $\mathrm{P}$ efficiency in bread wheat. Like shoot $\mathrm{P}$ concentrations, also severity of leaf symptoms did not correlate with $\mathrm{P}$ efficiency ratio (data not shown).

In most cases, genotypes showing higher $\mathrm{P}$ efficiency had higher shoot dry matter production under low supply of P. Consequently, the correlation between $\mathrm{P}$ efficiency ratio and the shoot dry weight of genotypes at low $\mathrm{P}$ supply was highly significant $\left(R^{2}=\right.$ $0.385^{* * *}$ ) (Figure 2). Absolute shoot dry weight of genotypes at low $\mathrm{P}$ supply significantly correlated with $\mathrm{P}$ content, but there was no relationship between absolute shoot dry weight and shoot $\mathrm{P}$ concentration (Figure 3). The contribution of seed $\mathrm{P}$ concentration to high $\mathrm{P}$ efficiency was very low and not significant for all wheat genotypes (Figure 4). Even, in the case of durum wheat genotypes there was an inverse trend between seed $\mathrm{P}$ concentration and $\mathrm{P}$ efficiency. Also the total amount (content) of $\mathrm{P}$ per seed, like seed $\mathrm{P}$ concentration, had a minimal contribution to differential P efficiency in all genotypes. For durum wheat genotypes the correlation between total amount of $\mathrm{P}$ per seed and $\mathrm{P}$ efficiency was in negative direction. These results imply no or very low contribution of seed $\mathrm{P}$ reserves to the presented variation in $\mathrm{P}$ efficiency of wheat.

\section{Discussion}

The present study with 39 bread and 34 durum wheat genotypes indicates that there is substantial genetic variation for P efficiency in wheat. Wheat genotypes differed significantly both in growth at low $\mathrm{P}$ supply and in response to $\mathrm{P}$ fertilization (Tables 1 and 2). 
Table 1. Effect of low $\left(\mathrm{P}_{20}=20 \mathrm{mg} \mathrm{P} \mathrm{kg}^{-1}\right.$ soil $)$ and adequate $\left(\mathrm{P}_{80}=80 \mathrm{mg} \mathrm{P} \mathrm{kg}^{-1}\right.$ soil $) \mathrm{P}$ supply on shoot dry matter production and $\mathrm{P}$ efficiency ratio of 39 bread wheat genotypes grown for 39 days under greenhouse conditions. Phosphorus efficiency was calculated as: [(dry matter production at $\mathrm{P}_{20} / \mathrm{dry}$ matter production at $\left.\mathrm{P}_{80}\right) \times 100$ ]

\begin{tabular}{|c|c|c|c|c|}
\hline \multirow[b]{2}{*}{ Genotypes } & \multirow{2}{*}{$\begin{array}{l}\text { Leaf } \\
\text { symptoms }^{a}\end{array}$} & \multicolumn{2}{|c|}{ Dry matter production } & \multirow[b]{2}{*}{ P efficiency } \\
\hline & & $\mathrm{P}_{20}$ & $\mathrm{P}_{80}$ & \\
\hline & & \multicolumn{2}{|c|}{$\left(\right.$ mg plant $\left.^{-1}\right)$} & $(\%)$ \\
\hline $\mathrm{Ka}$ 'S'/NAC & 2.0 & 629 & 880 & 71.4 \\
\hline BUC/FLK//MYNA/VUL & 3.0 & 448 & 639 & 70.1 \\
\hline PFAU/Vee\#S & 2.0 & 549 & 793 & 69.3 \\
\hline Kayson // Pvn'S' & 3.5 & 520 & 761 & 68.3 \\
\hline 84 CZT 04-1 & 1.5 & 516 & 767 & 67.3 \\
\hline BOW//BUC/BUL-1 & 3.5 & 495 & 743 & 66.7 \\
\hline 84 CZT 04-2 & 3.0 & 579 & 876 & 66.1 \\
\hline$(4777 / 2) / / \mathrm{Fkn} / 6 \mathrm{~b}$ & 3.0 & 442 & 680 & 65.0 \\
\hline ECTD-21 (Ziyabey-98) & 3.0 & 579 & 897 & 64.6 \\
\hline Cumhuriyet-75 & 2.0 & 530 & 822 & 64.5 \\
\hline Aday $98-1$ & 3.0 & 483 & 758 & 63.6 \\
\hline Pehlivan & 1.5 & 493 & 774 & 63.6 \\
\hline Gonen & 2.5 & 473 & 749 & 63.1 \\
\hline PWN'S’/SPRW'S' & 3.0 & 428 & 678 & 63.0 \\
\hline Nurkent & 3.0 & 507 & 808 & 62.7 \\
\hline Izmir-85 & 3.0 & 489 & 782 & 62.6 \\
\hline Aday $98-2$ & 1.5 & 345 & 558 & 61.9 \\
\hline Atilla & 3.0 & 563 & 918 & 61.3 \\
\hline Pamukova-97 & 2.0 & 480 & 785 & 61.1 \\
\hline BOW / BUC / Bul-2 & 4.0 & 425 & 700 & 60.7 \\
\hline Bandirma-97 & 2.0 & 508 & 838 & 60.7 \\
\hline KAUZ & 3.0 & 377 & 621 & 60.7 \\
\hline Genc-88 & 3.5 & 614 & 1023 & 60.0 \\
\hline RSK/5/21931/3/ & 3.0 & 387 & 651 & 59.4 \\
\hline Panda & 2.0 & 534 & 901 & 59.3 \\
\hline Kasifbey-95 & 2.0 & 438 & 743 & 58.9 \\
\hline BOW//TTR'S’/Bow'S’ & 3.0 & 393 & 670 & 58.7 \\
\hline BOW'S’/Crow'S’-3 & 2.5 & 394 & 672 & 58.7 \\
\hline Seri-82 & 2.0 & 479 & 821 & 58.4 \\
\hline Ures/Bow 'S' & 2.5 & 376 & 657 & 57.3 \\
\hline Basribey-95 & 2.0 & 417 & 728 & 57.2 \\
\hline Karacabey-97 & 2.0 & 398 & 703 & 56.5 \\
\hline BOW 'S’/Crow ‘S’-1 & 3.0 & 455 & 810 & 56.2 \\
\hline Chill'S' & 3.0 & 396 & 706 & 56.1 \\
\hline Golia & 1.5 & 370 & 660 & 56.1 \\
\hline Karacadag & 3.5 & 518 & 930 & 55.6 \\
\hline BOW'S'/Crow'S’-2 & 3.0 & 424 & 774 & 54.8 \\
\hline BOW‘S'/Crow ‘S’-4 & 3.0 & 443 & 811 & 54.7 \\
\hline BOW‘S’/Crow ‘S’-2 & 2.5 & 413 & 818 & 50.6 \\
\hline Mean & 2.6 & 469 & 767 & 61.2 \\
\hline $\mathrm{LSD}_{0.05}(\mathrm{C}, \mathrm{P}, \mathrm{C} \times \mathrm{P})$ & & & NS) & \\
\hline
\end{tabular}

${ }^{a}$ Leaf symptoms of P deficiency: 1 (very severe) to 5 (very slight or no symptoms). 
Table 2. Effect of low $\left(\mathrm{P}_{20}=20 \mathrm{mg} \mathrm{P} \mathrm{kg}^{-1}\right.$ soil $)$ and adequate $\left(\mathrm{P}_{80}=80 \mathrm{mg} \mathrm{P} \mathrm{kg}^{-1}\right.$ soil $) \mathrm{P}$ supply on shoot dry matter production and $\mathrm{P}$ efficiency ratio of 34 durum wheat genotypes grown for 39 days under greenhouse conditions. Phosphorus efficiency was calculated as: [(dry matter production at $\mathrm{P}_{20}$ /dry matter production at $\left.\left.\mathrm{P}_{80}\right) \times 100\right]$

\begin{tabular}{|c|c|c|c|c|}
\hline \multirow[b]{2}{*}{ Genotypes } & \multirow{2}{*}{$\begin{array}{l}\text { Leaf } \\
\text { symptoms }^{a}\end{array}$} & \multicolumn{2}{|c|}{ Dry matter production } & \multirow[b]{2}{*}{$\mathrm{P}$ efficiency } \\
\hline & & $\mathrm{P}_{20}$ & $\mathrm{P}_{80}$ & \\
\hline & & \multicolumn{2}{|c|}{$\left(\right.$ mg plant $\left.{ }^{-1}\right)$} & $(\%)$ \\
\hline Aw 12/Bit & 3.5 & 598 & 760 & 78.6 \\
\hline Diyarbakir-81 & 3.0 & 614 & 788 & 77.9 \\
\hline Ceylan-95 & 3.0 & 558 & 751 & 74.4 \\
\hline Haucan / Omrabi 12 & 4.0 & 594 & 817 & 72.8 \\
\hline Cham1 / Brachoma & 2.0 & 513 & 721 & 71.1 \\
\hline Amanos-97 & 3.0 & 533 & 755 & 70.6 \\
\hline Mrb 16/3/EN+e & 3.5 & 649 & 930 & 69.8 \\
\hline Stojucri-6 & 3.5 & 593 & 851 & 69.7 \\
\hline Saricanak-98 & 4.0 & 588 & 844 & 69.6 \\
\hline 93 CZT-11-6 & 2.0 & 516 & 743 & 69.5 \\
\hline Bagan-5 & 3.5 & 583 & 842 & 69.2 \\
\hline 93 CZT-11-3 & 2.5 & 517 & 756 & 68.4 \\
\hline Cakmak & 2.0 & 442 & 654 & 67.5 \\
\hline Altintoprak-98 & 3.5 & 539 & 802 & 67.3 \\
\hline Balcali & 3.0 & 610 & 908 & 67.2 \\
\hline Ege- 88 & 2.5 & 622 & 928 & 67.0 \\
\hline Salihli-92 & 3.5 & 558 & 838 & 66.7 \\
\hline Jabiru-4 & 2.5 & 688 & 893 & 66.5 \\
\hline 93 CZT-10-4 & 3.5 & 556 & 837 & 66.4 \\
\hline STN`S’ & 3.5 & 461 & 713 & 64.7 \\
\hline Harran-95 & 3.5 & 525 & 819 & 64.1 \\
\hline $\mathrm{Av} /-1 / \mathrm{Sb} / 4$ & 4.0 & 553 & 868 & 63.7 \\
\hline 93 CZT-10-2 & 3.5 & 533 & 838 & 63.6 \\
\hline Omrabi-5/Omguer-3 & 3.5 & 495 & 778 & 63.6 \\
\hline Aydin-93 & 3.5 & 544 & 868 & 62.7 \\
\hline Omrabi-3 & 4.0 & 553 & 886 & 62.5 \\
\hline Mque / Oyca'S' & 3.5 & 532 & 857 & 62.1 \\
\hline Omruf-2 & 3.5 & 553 & 894 & 61.9 \\
\hline Sabil-1 & 3.0 & 530 & 865 & 61.3 \\
\hline Chacan & 3.5 & 486 & 804 & 60.4 \\
\hline Skarv-13 & 2.0 & 483 & 819 & 58.9 \\
\hline Firat-93 & 3.0 & 478 & 811 & 58.9 \\
\hline Yazi-40 & 3.5 & 515 & 911 & 56.5 \\
\hline Gediz-75 & 3.0 & 453 & 972 & 46.7 \\
\hline Mean & 3.2 & 546 & 827 & 65.9 \\
\hline $\mathrm{LSD}_{0.05}(\mathrm{C}, \mathrm{P}, \mathrm{C} \times \mathrm{P})$ & & & NS) & \\
\hline
\end{tabular}

${ }^{a}$ Leaf symptoms of P deficiency: 1 (very severe) to 5 (very slight or no symptoms).

Such substantial genetic variation in response to $\mathrm{P}$ deficiency and $\mathrm{P}$ supply was also shown for a large number of wheat cultivars grown in Australia (Batten, 1986; Osborne and Rengel, 2002a) and at CIMMYT (Manske et al., 2000). The reason for such wide ge- netic variation in P efficiency in wheat could not be understood. In the present study there was no correlation between shoot $\mathrm{P}$ concentration and $\mathrm{P}$ efficiency (Figure 1). Even, in the case of durum wheat, the genotypes with higher P efficiency tended to have less shoot 


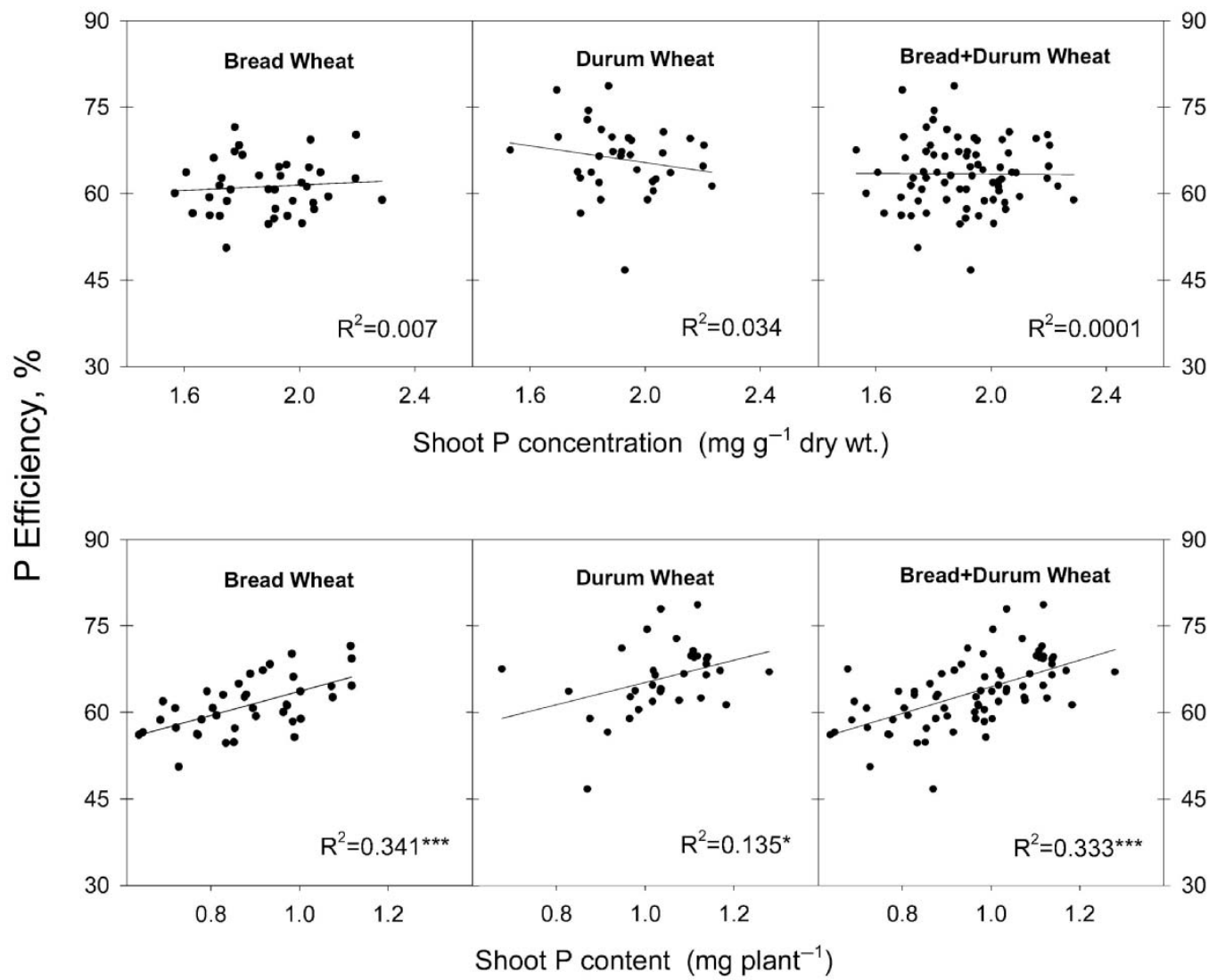

Figure 1. Relationship between $\mathrm{P}$ efficiency (relative shoot growth) and shoot $\mathrm{P}$ concentration and content (total amount of $\mathrm{P}$ per plant) of 39 bread and 34 durum wheat genotypes grown with low P supply $\left(20 \mathrm{mg} \mathrm{P} \mathrm{kg}^{-1}\right.$ soil) for 39 days under greenhouse conditions.

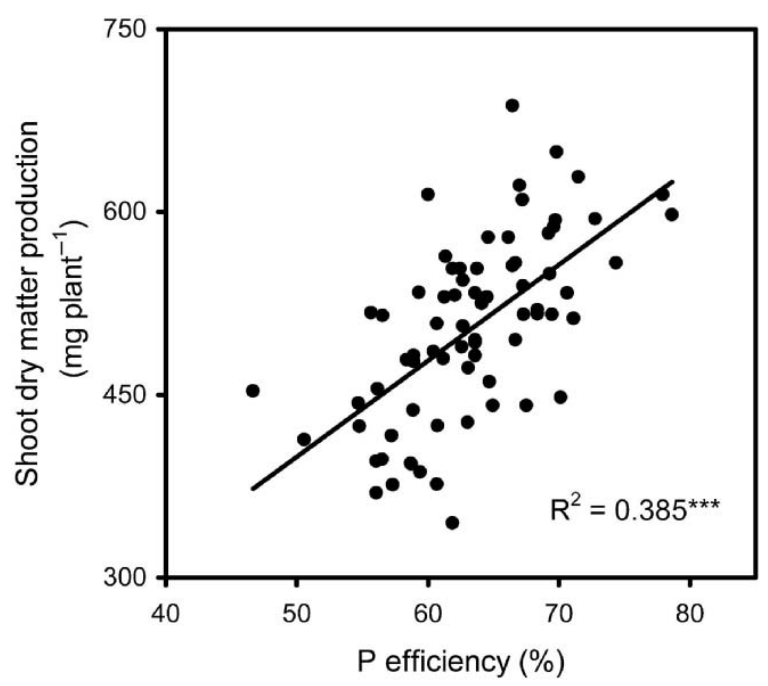

Figure 2. Relationship between P efficiency (relative shoot growth) and shoot dry matter production of 73 wheat genotypes grown under low $\mathrm{P}\left(20 \mathrm{mg} \mathrm{P} \mathrm{kg}^{-1}\right.$ soil) supply.
P concentration when compared to the genotypes with lower P efficiency ratios (Figure 1). This suggests that shoot $\mathrm{P}$ concentration is not a reliable criterion in assessing wheat genotypes for P efficiency. Also Jones et al. (1992) and Fageria and Baligar (1999) could not find a relationship between plant $\mathrm{P}$ concentration and $\mathrm{P}$ efficiency in wheat cultivars. By contrast, there is a better relationship between the total amount of $\mathrm{P}$ per shoot and $\mathrm{P}$ efficiency of genotypes. Also absolute shoot dry weight at low $\mathrm{P}$ supply correlated very well with total amount of $\mathrm{P}$ per shoot, but not with $\mathrm{P}$ concentration in shoot (Figure 3 ). These may indicate a contribution of enhanced $\mathrm{P}$ uptake in expression of high $\mathrm{P}$ efficiency. In most studies, the total amount of $\mathrm{P}$ per shoot or per plant is considered as 'P uptake' (Fageria and Baligar, 1997 and 1999; Gill et al., 1994; Jones et al., 1989 and 1992). However, in these studies, the total amount of $\mathrm{P}$ per shoot is calculated by multiplying dry matter production with $\mathrm{P}$ concentration, and may not represent 'the absolute amount of P taken up' by roots. The total amount of 
Table 3. Effect of low $\left(\mathrm{P}_{20}=20 \mathrm{mg} \mathrm{P} \mathrm{kg}^{-1}\right.$ soil $)$ and adequate $\left(\mathrm{P}_{80}=80 \mathrm{mg} \mathrm{P} \mathrm{kg}^{-1}\right.$ soil $) \mathrm{P}$ supply on shoot concentration and content (total amount) of $\mathrm{P}$ in 39 bread wheat genotypes grown for 39 days under greenhouse conditions

\begin{tabular}{|c|c|c|c|c|}
\hline \multirow[b]{2}{*}{ Genotypes } & \multicolumn{2}{|c|}{ Shoot $\mathrm{P}$ concentration } & \multicolumn{2}{|c|}{ Shoot $\mathrm{P}$ content } \\
\hline & $\mathrm{P}_{20}$ & $\mathrm{P}_{80}$ & $\mathrm{P}_{20}$ & $\mathrm{P}_{80}$ \\
\hline & \multicolumn{2}{|c|}{ (mg g ${ }^{-1}$ dry wt) } & \multicolumn{2}{|c|}{$\left(\mathrm{mg} \mathrm{plant}^{-1}\right)$} \\
\hline $\mathrm{Ka}$ 'S'/NAC & 1.78 & 3.47 & 1.12 & 3.05 \\
\hline BUC/FLK//MYNA/VUL & 2.20 & 3.83 & 0.98 & 2.45 \\
\hline PFAU/Vee\#S & 2.04 & 3.78 & 1.12 & 2.97 \\
\hline Kayson//Pvn'S' & 1.79 & 4.08 & 0.93 & 3.11 \\
\hline 84 CZT 04-1 & 1.78 & 3.46 & 0.92 & 2.64 \\
\hline BOW//BUC/BUL-1 & 1.80 & 3.71 & 0.89 & 2.75 \\
\hline 84 CZT 04-2 & 1.70 & 3.24 & 0.99 & 2.83 \\
\hline$(4777 / 2) / / \mathrm{Fkn} / 6 \mathrm{~b}$ & 1.96 & 4.46 & 0.86 & 3.03 \\
\hline ECTD-21 (Ziyabey-98) & 1.93 & 4.04 & 1.12 & 3.62 \\
\hline Cumhuriyet-75 & 2.03 & 4.32 & 1.07 & 3.55 \\
\hline Aday 98-1 & 2.07 & 4.06 & 1.00 & 3.08 \\
\hline Pehlivan & 1.61 & 3.98 & 0.79 & 3.08 \\
\hline Gonen & 1.86 & 4.05 & 0.88 & 3.02 \\
\hline PWN'S’/SPRW'S' & 1.93 & 3.96 & 0.83 & 2.69 \\
\hline Nurkent & 1.73 & 3.66 & 0.88 & 2.96 \\
\hline Izmir-85 & 2.20 & 4.39 & 1.08 & 3.43 \\
\hline Aday $98-2$ & 2.01 & 4.02 & 0.69 & 2.24 \\
\hline Atilla & 1.72 & 3.91 & 0.97 & 3.58 \\
\hline Pamukova-97 & 2.03 & 4.21 & 0.97 & 3.29 \\
\hline BOW/BUC/Bul-2 & 1.89 & 3.59 & 0.80 & 2.51 \\
\hline Bandirma-97 & 1.76 & 4.08 & 0.90 & 3.42 \\
\hline KAUZ & 1.91 & 3.68 & 0.72 & 2.29 \\
\hline Genc-88 & 1.57 & 2.80 & 0.96 & 2.85 \\
\hline RSK/5/21931/3/ & 2.10 & 4.02 & 0.81 & 2.60 \\
\hline Panda & 1.69 & 3.65 & 0.90 & 3.26 \\
\hline Kasifbey-95 & 2.29 & 4.11 & 1.00 & 3.06 \\
\hline BOW//TTR'S’/Bow ‘S’ & 1.98 & 4.13 & 0.78 & 2.77 \\
\hline BOW'S’/Crow‘S’-3 & 1.75 & 3.68 & 0.69 & 2.47 \\
\hline Seri-82 & 2.05 & 3.85 & 0.99 & 3.13 \\
\hline Ures / Bow 'S' & 1.92 & 3.68 & 0.72 & 2.42 \\
\hline Basribey-95 & 2.05 & 3.95 & 0.85 & 2.88 \\
\hline Karacabey-97 & 1.63 & 4.39 & 0.65 & 3.08 \\
\hline BOW'S' / Crow ‘S’-1 & 1.69 & 3.93 & 0.77 & 3.19 \\
\hline Chill'S' & 1.96 & 4.05 & 0.77 & 2.85 \\
\hline Golia & 1.72 & 4.49 & 0.64 & 2.96 \\
\hline Karacadag & 1.91 & 3.61 & 0.99 & 3.35 \\
\hline BOW'S'/Crow'S'-2 & 2.01 & 3.97 & 0.85 & 3.08 \\
\hline BOW'S'/Crow'S’-4 & 1.89 & 3.95 & 0.83 & 3.19 \\
\hline BOW'S’/Crow'S’-2 & 1.75 & 3.87 & 0.73 & 3.16 \\
\hline Mean & 1.89 & 3.90 & 0.88 & 2.97 \\
\hline $\mathrm{LSD}_{0.05}(\mathrm{C}, \mathrm{P}, \mathrm{C} \times \mathrm{P})$ & $(0.1$ & $0.27)$ & $(0.21$ & $0.31)$ \\
\hline
\end{tabular}


Table 4. Effect of low $\left(\mathrm{P}_{20}=20 \mathrm{mg} \mathrm{P} \mathrm{kg}^{-1}\right.$ soil $)$ and adequate $\left(\mathrm{P}_{80}=80 \mathrm{mg} \mathrm{P} \mathrm{kg}^{-1}\right.$ soil $) \mathrm{P}$ supply on shoot concentration and content (total amount) of $\mathrm{P}$ in 34 durum wheat genotypes grown for 39 days under greenhouse conditions

\begin{tabular}{|c|c|c|c|c|}
\hline \multirow[b]{2}{*}{ Genotypes } & \multicolumn{2}{|c|}{ Shoot $\mathrm{P}$ concentration } & \multicolumn{2}{|c|}{ Shoot $\mathrm{P}$ content } \\
\hline & $\mathrm{P}_{20}$ & $\mathrm{P}_{80}$ & $\mathrm{P}_{20}$ & $\mathrm{P}_{80}$ \\
\hline & \multicolumn{2}{|c|}{$\left(\mathrm{mg} \mathrm{g}^{-1}\right.$ dry wt) } & \multicolumn{2}{|c|}{ (mg plant ${ }^{-1}$ ) } \\
\hline Aw 12/Bit & 1.87 & 3.51 & 1.12 & 2.67 \\
\hline Diyarbakir-81 & 1.69 & 3.95 & 1.04 & 3.12 \\
\hline Ceylan-95 & 1.80 & 3.73 & 1.00 & 2.80 \\
\hline Haucan/Omrabi 12 & 1.80 & 3.50 & 1.07 & 2.86 \\
\hline Cham1/Brachoma & 1.85 & 4.13 & 0.95 & 2.98 \\
\hline Amanos-97 & 2.06 & 4.62 & 1.11 & 3.48 \\
\hline Mrb16/3/EN+e & 1.70 & 3.69 & 1.10 & 3.42 \\
\hline Stojucri-6 & 1.88 & 4.18 & 1.12 & 3.53 \\
\hline Saricanak-98 & 1.94 & 3.78 & 1.14 & 3.19 \\
\hline 93 CZT-11-6 & 2.16 & 4.74 & 1.11 & 3.51 \\
\hline Bagan-5 & 1.95 & 4.13 & 1.14 & 3.47 \\
\hline 93 CZT-11-3 & 2.20 & 4.74 & 1.14 & 3.58 \\
\hline Cakmak & 1.53 & 4.07 & 0.68 & 2.67 \\
\hline Altintoprak-98 & 1.89 & 3.72 & 1.02 & 2.98 \\
\hline Balcali & 1.92 & 3.85 & 1.17 & 3.49 \\
\hline Ege- 88 & 2.06 & 4.46 & 1.28 & 4.14 \\
\hline Salihli-92 & 1.95 & 4.13 & 1.09 & 3.45 \\
\hline Jabiru-4 & 1.92 & 3.55 & 1.14 & 3.18 \\
\hline 93 CZT-10-4 & 1.84 & 4.06 & 1.02 & 3.40 \\
\hline STN`S’ & 2.20 & 4.67 & 1.02 & 3.32 \\
\hline Harran-95 & 1.97 & 3.61 & 1.04 & 2.96 \\
\hline $\mathrm{Av} /-1 / \mathrm{Sb} / 4$ & 1.77 & 3.45 & 0.98 & 3.00 \\
\hline 93 CZT-10-2 & 1.81 & 4.03 & 0.83 & 3.38 \\
\hline Omrabi-5/Omguer-3 & 2.09 & 4.16 & 1.03 & 3.24 \\
\hline Aydin-93 & 1.78 & 3.30 & 0.97 & 2.86 \\
\hline Omrabi-3 & 2.04 & 4.45 & 1.13 & 3.90 \\
\hline Mque/Oyca'S' & 2.03 & 4.66 & 1.08 & 3.99 \\
\hline Omruf-2 & 1.84 & 3.61 & 1.02 & 3.23 \\
\hline Sabil-1 & 2.23 & 4.63 & 1.18 & 3.98 \\
\hline Chacan & 2.03 & 4.10 & 0.99 & 3.30 \\
\hline Skarv-13 & 2.01 & 4.60 & 0.97 & 3.78 \\
\hline Firat-93 & 1.85 & 4.29 & 0.88 & 3.48 \\
\hline Yazi-40 & 1.78 & 3.64 & 0.92 & 3.32 \\
\hline Gediz-75 & 1.93 & 3.76 & 0.87 & 3.64 \\
\hline Mean & 1.92 & 4.05 & 1.04 & 3.33 \\
\hline $\mathrm{LSD}_{0.05}(\mathrm{C}, \mathrm{P}, \mathrm{C} \times \mathrm{P})$ & & $0.26)$ & $(0.30$ & 0.39 \\
\hline
\end{tabular}

P per shoot (or per plant) is a calculated value by considering shoot dry matter yield, and therefore it can be greatly affected by habitus, growth rate and even harvest index of genotypes. Genotypes with inherently different growth rate or habitus (e.g., tall or dwarf cultivars; slower or faster growth rate etc.) may have same P uptake rate per root dry weight, but they can differ in the total amount of $\mathrm{P}$ (calculated $\mathrm{P}$ amount) per shoot due to inherent variation in shoot dry matter production per time. It is, therefore, not entirely clear if the higher dry matter production of P-efficient genotypes is achieved by enhanced $\mathrm{P}$ uptake by roots, 

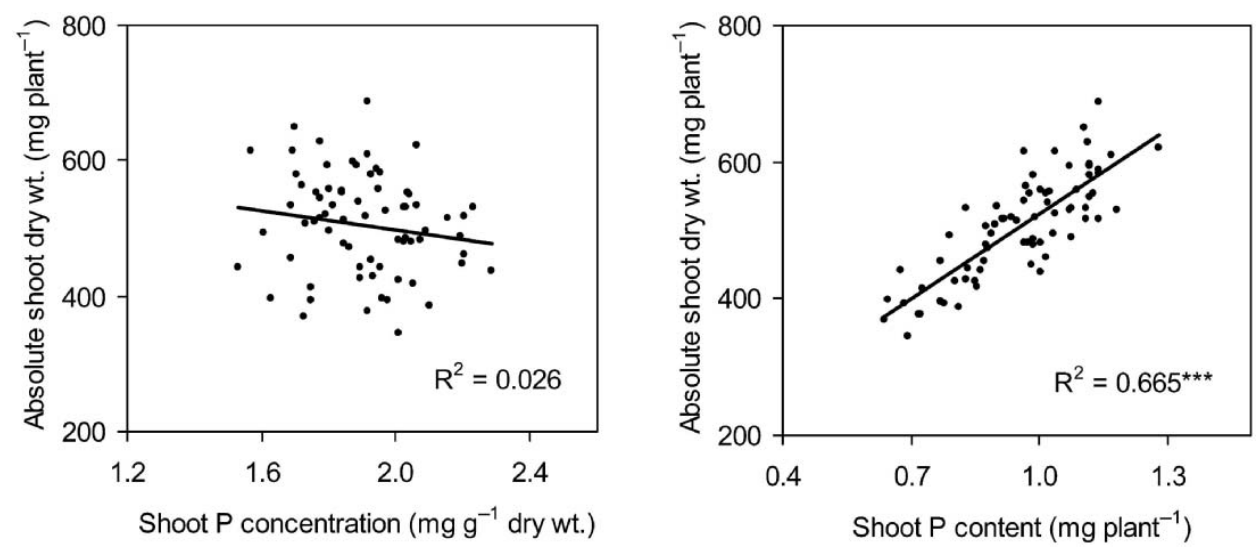

Figure 3. Relationship between absolute shoot dry weight and shoot $\mathrm{P}$ concentration and content of 73 wheat genotypes grown under low $\mathrm{P}$ (20 $\mathrm{mg} \mathrm{P} \mathrm{kg}^{-1}$ soil) supply.

or alternatively the greater amount of $\mathrm{P}$ per shoot is caused by better growth under low supply of P. In the latter case, $\mathrm{P}$ taken up by plants is used efficiently at the cellular level to contribute to better shoot growth at low $\mathrm{P}$ supply. It might be argued that the proportion of physiologically active $\mathrm{P}$ in the total amount of $\mathrm{P}$ might be higher in most of P-efficient genotypes than the P-inefficient genotypes, contributing to better dry matter production under $\mathrm{P}$ deficient conditions. This point needs to be studied in more detail.

Irrespective of the underlying mechanism, a higher absolute shoot dry matter production or grain yield under P deficiency appears to be the most reliable parameter for screening genotypes for $\mathrm{P}$ efficiency. As presented in Tables 1 and 2, genotypes having very similar shoot growth at adequate $\mathrm{P}$ supply, showed large differences in shoot growth under $\mathrm{P}$ deficiency. There was a highly significant correlation $\left(R^{2}=\right.$ $0.385^{* * *}$ ) between $\mathrm{P}$ efficiency and absolute shoot dry weight at low P supply (Figure 2), indicating that shoot growth at low $\mathrm{P}$ supply can be an appropriate parameter for P efficiency. In good agreement with results presented here, absolute shoot dry matter production was also successfully used by Fageria and Baligar (1999) and Osborne and Rengel (2002a) for ranking wheat genotypes for P efficiency. Similarly, also in other crop species such as tomato and rice, shoot dry weight at low $\mathrm{P}$ supply was considered as a screening parameter for P efficiency (Coltman et al., 1986; Fageria et al., 1988). Use of shoot growth as a criterion in ranking genotypes for $\mathrm{P}$ efficiency can have limitations for germplasm in which genotypes have considerable variation in growth rates at adequate $P$ supply or variation in habit (e.g., tall and dwarf genotypes). In wheat germplasm used in the present study many genotypes showed similar shoot dry weight at adequate $\mathrm{P}$ supply. More than $60 \%$ of the 73 wheat genotypes had a shoot dry weight ranging between 700 to $850 \mathrm{mg}$ per plant at adequate $\mathrm{P}$ supply (Tables 1 and 2 ).

Severity of leaf symptoms of P deficiency could be a further parameter in screening genotypes for $\mathrm{P}$ efficiency. As reported by Elliott et al. (1997) P deficiency symptoms on wheat leaves are not characteristic, especially in plants under moderate $\mathrm{P}$ deficiency stress. At early stages of $\mathrm{P}$ deficiency stress, leaves appeared dark green, and with time the oldest leaves became chlorotic and necrotic beginning from the leaf tip. All genotypes tested in the present study have been scored for the severity of $\mathrm{P}$ deficiency symptoms on leaves before the harvest to evaluate its relation to $\mathrm{P}$ efficiency. Leaf symptoms of $\mathrm{P}$ deficiency was totally independent of leaf $\mathrm{P}$ concentration or content, and there was no relation between severity of symptoms and $\mathrm{P}$ efficiency ratio of the genotypes suggesting that $\mathrm{P}$ deficiency symptoms cannot be a good selection criterion to distinguish $\mathrm{P}$ efficient and inefficient wheat genotypes. Interestingly, certain genotypes with very high P efficiency (e.g. Ka 'S'/NAC and 84 CZT04/1) showed very severe $\mathrm{P}$ deficiency symptoms on leaves (Table 1). This may indicate a high P-retranslocation from old leaves to newly growing parts (e.g. meristems) of the roots and shoot, resulting in a better dry matter production, but causing more symptoms of $\mathrm{P}$ deficiency. The contribution of enhanced $\mathrm{P}$ retranslocation capacity to expression of high $\mathrm{P}$ efficiency has been discussed in studies with sorghum (Furlani et al., 1984) and bean genotypes (Youngdahl, 1990). More detailed experiments are needed for a better under- 


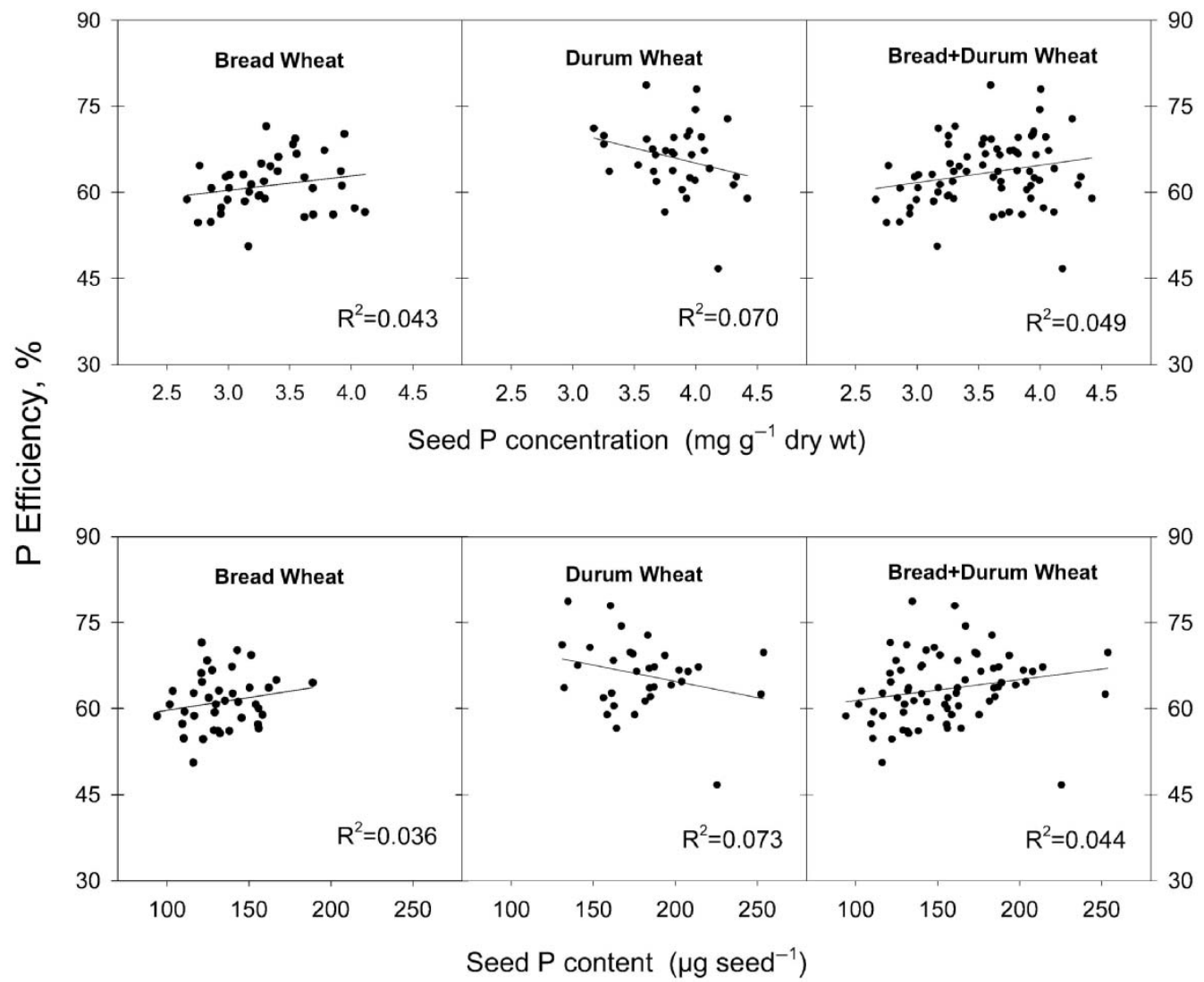

Figure 4. Relationship between $\mathrm{P}$ efficiency (relative shoot growth) and seed $\mathrm{P}$ concentration and content (total amount of $\mathrm{P}$ per seed) of 39 bread and 34 durum wheat genotypes grown with low $\mathrm{P}$ supply $\left(20 \mathrm{mg} \mathrm{P} \mathrm{kg}^{-1}\right.$ soil) for 39 days under greenhouse conditions.

standing of the role of $\mathrm{P}$ retranslocation in P efficiency in wheat.

Seed concentration of $\mathrm{P}$ can greatly affect plant performance under low $\mathrm{P}$ supply as shown in wheat (Zhu and Smith, 2001), especially at early growth stages. In large seeded species like bean, higher seed size and higher $\mathrm{P}$ concentration of seed can contribute to higher $\mathrm{P}$ efficiency, and therefore, should be considered in evaluation of genotypes for $\mathrm{P}$ efficiency (Yan et al., 1995; Teixeira et al., 1999; Liao and Yan, 1999). In contrast to these results in bean with large seeds, the variation in both seed $\mathrm{P}$ concentration and $\mathrm{P}$ content for most of the genotypes were not related to differential P efficiency in wheat (Figure 4), indicating that genotypic variation for $\mathrm{P}$ efficiency found in the present study is rather inherent and not related to seed $\mathrm{P}$ concentration or seed size. This result is in good agreement with the results of Osborne and Rengel (2002a) in several Australian wheat cultivars. However, for a limited number of genotypes given in Figure 4, the correlation between P efficiency and seed
$P$ reserve could be positive, indicating that depending on the genotypes used the seed $\mathrm{P}$ reserve could contribute to $\mathrm{P}$ efficiency.

Phosphorus efficiency is a very complex phenomenon and affected by large number of plant mechanisms associated with $\mathrm{P}$ acquisition from soil and P utilization at cellular level (Gourley et al., 1994; Marschner, 1995; Schachtman et al., 1998; Lynch and Ho, 2004). Very recently, Wissuwa (2003) suggested that large differences in tolerance to $\mathrm{P}$ deficiency within rice genotypes are caused by small changes in mechanisms affecting $\mathrm{P}$ deficiency tolerance, and such small changes are generally difficult to detect. There is no general mechanism that determines the extent of $\mathrm{P}$ efficiency in crop plants. Plant mechanisms affecting differential expression of $\mathrm{P}$ efficiency are generally studied in a limited number of genotypes, in most cases in only 2 contrasting genotypes of a given species. The results obtained from such studies cannot be often applied to other genotypes of the same or different species. As presented in Figure 1, among 
the 73 wheat genotypes grown under same condition, genotypes can be selected (found) showing an excellent correlation between $\mathrm{P}$ efficiency and $\mathrm{P}$ content leading to a suggestion that $\mathrm{P}$ acquisition ability of genotypes is a decisive factor in expression of high $\mathrm{P}$ efficiency. Alternatively, from Figure 1, genotypes can be selected which are more or less same in $\mathrm{P}$ content (or $\mathrm{P}$ concentration), but differing greatly in $\mathrm{P}$ efficiency, leading to a suggestion that $\mathrm{P}$ utilization ability is the most critical factor in expression of high $\mathrm{P}$ efficiency. It seems likely that $\mathrm{P}$ efficiency mechanisms may be different among the genotypes of a given species. This point needs particular attention in the evaluation of physiological and genetic factors or mechanisms affecting expression of high $\mathrm{P}$ efficiency in plants. In the future research, identification of $\mathrm{P}$ efficiency mechanisms should be studied preferentially in a large number of genotypes.

In conclusion, the shoot dry matter production and total amount of $\mathrm{P}$ per shoot at low $\mathrm{P}$ treatment are the most reliable parameters in assessing wheat genotypes for their $\mathrm{P}$ efficiency at the vegetative stage. Phosphorus concentration in shoots and seeds of the genotypes used in the present study had no relation to $\mathrm{P}$ efficiency ratio. Similarly, also severity of leaf $\mathrm{P}$ deficiency symptoms did not show any relation to $\mathrm{P}$ efficiency and shoot $\mathrm{P}$ concentration, indicating that scoring genotypes for severity of leaf symptoms is not appropriate to distinguish P-efficient and P-inefficient genotypes. The genetic variation within 73 wheat genotypes for P efficiency is substantial and could be exploited in breeding for P-efficient and high-yielding new genotypes for P-deficient calcareous soils.

\section{Acknowledgements}

This study is part of Levent Ozturk's PhD thesis. The authors are grateful to TUBITAK (Technical and Scientific Research Council of Turkey) and Cukurova University Research Fund for their financial support.

\section{References}

Barton C J 1948 Photometric analysis on phosphate rock. Ind. Anal. Eng. Chem. 20, 1068-1073.

Bates T R and Lynch J P 2001 Root hairs confer a competitive advantage under low phosphorus availability. Plant Soil 236, 243-250.

Batjes N H 1997 A world data set of derived soil properties by FAOUNESCO soil unit for global modelling. Soil Use Manag. 13, 9-16.
Batten G D 1986 The uptake and utilisation of phosphorus and nitrogen by diploid, tetraploid and hexaploid wheats (Triticum spp.). Annals Bot. 58, 49-59.

Cakmak I 2002 Plant nutrition research: Priorities to meet human needs for food in sustainable ways. Plant Soil 247, 3-24.

Coltman R R, Gerloff G C and Gabelman W H 1986 Equivalent stress comparisons for evaluating physiological and morphological differences among tomato strains differentially tolerant to $\mathrm{P}$ deficiency. J. Am. Soc. Hort. Sci., 111(3), 422-426.

Elliott D E, Reuter D J, Reddy G D and Abbott R J 1997 Phosphorus nutrition of spring wheat (Triticum aestivum L.) 1. Effects of phosphorus supply on plant symptoms, yield, components of yield, and plant phosphorus uptake. Aust. J. Agr. Res. 48, $855-867$.

Eyupoglu F 1999 Türkiye topraklarinin verimlilik durumu. Soil and Fertilizer Res. Inst. General Publications No: 220, Ankara, Turkey. $221 \mathrm{pp}$.

Fageria N K and Baligar V C 1997 Upland rice genotypes evaluation for phosphorus use efficiency. J. Plant Nutr., 20, 499-509.

Fageria N K and Baligar V C 1999 Phosphorus-use efficiency in wheat genotypes. J. Plant Nutr. 22, 331-340.

Fageria N K, Wright R J and Baligar V C 1988 Rice cultivar evaluation for phosphorus-use efficiency. Plant Soil 111, 105-109.

Furlani A M C, Clark R B, Maranville J W and Ross W M 1984 Root phosphatase activity of sorghum genotypes grown with organic and inorganic sources of phosphorus. J. Plant Nutr. 7, 1583-1595.

Gahoonia T S, Nielsen N E and Lyshede O B 1999 Phosphorus (P) acquisition of cereal cultivars in the field at three levels of P fertilization. Plant Soil, 211, 269-281.

Gill M A, Rahmatullah and Salim M 1994 Growth responses of twelve wheat cultivars and their phosphorus utilization from rock phosphate. J. Agron. Crop. Sci. 173, 204-209.

Gourley C J P, Allan D L and Russelle M P 1994 Plant nutrient efficiency: A comparison of definitions and suggested improvement. Plant Soil 158, 29-37.

Hash C T, Schaffert R E and Peacock J M 2002 Prospects for using conventional techniques and molecular biological tools to enhance performance of 'orphan' crop plants on soils low in available phosphorus. Plant Soil 245, 135-146.

Horst W J, Abdou M and Wiesler F 1993 Genotypic differences in phosphorus efficiency of wheat. Plant Soil 155/156, 293-296.

Jones G P D, Blair G J and Jessop R S 1989 Phosphorus efficiency in wheat - A useful selection criterion? Field Crops Res. 21, 257264.

Jones G P D, Jessop R S and Blair G J 1992 Alternative methods for the selection of phosphorus efficiency in wheat. Field Crops Res. 30, 29-40.

Liao K and Yan X 1999 Seed size is closely related to phosphorus use efficiency and photosynthetic phosphorus use efficiency in common bean. J. Plant Nutr. 22, 877-888.

Lynch J P and Ho M D 2004 Rhizoeconomics: Carbon costs of phosphorus acquisition. Plant Soil, (in press).

Manske G G B, Ortiz-Monasterio J I, Van Ginkel M, Gonzalez R M, Rajaram S, Molina E and Vlek P L G 2000 Traits associated with improved P-uptake efficiency in CIMMYT's semidwarf spring bread wheat grown on an acid andisol in Mexico. Plant Soil 221, 189-204.

Manske G G B, Ortiz-Monasterio J I, van Ginkel R M, Rajaram S and Vlek P L G 2002 Phosphorus use efficiency in tall, semidwarf and dwarf near-isogenic lines of spring wheat. Euphytica $125,113-119$. 
Marschner H 1995 Mineral Nutrition of Higher Plants, 2nd edn., Academic Press, London.

Olsen S R, Cole C V, Watanabe F S and Dean L A 1954 Estimation of Available Phosphorus in Soil by Extraction with Sodium Bicarbonate. USDA Circ., 939. U. S. Gov. Print Office, Washington, DC.

Osborne L D and Rengel Z 2002a Screening cereals for genotypic variation in efficiency of phosphorus uptake and utilization. Aust. J. Agr. Res. 53, 295-303.

Osborne L D and Rengel Z 2002b Genotypic differences in wheat for uptake and utilisation of P from iron phosphate. Aust. J. Agr. Res. 53, 837-844.

Osborne L D and Rengel Z 2002c Growth and P uptake by wheat genotypes supplied with phytate as the only P source. Aust. J. Agr. Res. 53, 845-850.

Reuter D J and Robinson J B 1997 Plant Analysis: An Interpretation Manual, 2nd edn., CSIRO Publishing, Australia.

Raghothama KG 1999 Phosphate acquisition. Annu. Rev. Plant Physiol. Plant Mol. Biol. 50, 665-693.

Rengel Z 1999 Physiological mechanisms underlying differential nutrient efficiency of crop genotypes. In Mineral Nutrition of Crops: Fundamental Mechanisms and Implications. Ed. Z. Rengel. pp. 227-265. Haworth Press, New York.

Schachtman P D, Reid R J and Ayling S M 1998 Phosphorus uptake by plants: from soil to cell. Plant Physiol. 116, 447-453.

Teixeira M G, Guilherme J, Guerra M, De Almeida D L, Araujo A P and Franco A A 1999 Effect of seed phosphorus concentration on nodulation and growth of three common bean cultivars. J. Plant Nutr. 22, 1599-1611.

Vance C P, Uhde-Stone C and Allan D L 2003 Phosphorus acquisition and use: critical adaptations by plants for securing a nonrenewable resource. New Phytol. 157, 423-447.

Wissuwa M 2003 How do plants achieve tolerance to phosphorus deficiency? Small causes with big effects. Plant Physiol. 133, 1947-1958.

Wissuwa M, Wegner J, Ae N and Yano M 2002 Substitution mapping of Pup1: a major QTL increasing phosphorus uptake of rice from a phosphorus-deficient soil. Theor. App. Gen. 105, 890-897.

Yan X, Liao H, Beebe S E, Blair M W and Lynch J P 2004 QTL mapping of root hair and acid exudation traits and their relationship to phosphorus uptake in common bean. Plant Soil (in press).

Yan X, Lynch J and Beebe S E 1995 Genetic variation for phosphorus efficiency of common bean in contrasting soil types: I. vegetative response. Crop Sci. 35, 1086-1093.

Yao Q, Li X L and Christie P 2001 Factors affecting arbuscular mycorrhizal dependency of wheat genotypes with different phosphorus efficiencies. J. Plant Nutr. 24, 1409-1419.

Youngdahl L J 1990 Differences in phosphorus efficiency in bean genotypes. J. Plant Nutr. 13, 1381-1392.

Zhu Y G and Smith S E 2001 Seed phosphorus (P) content affects growth, and $\mathrm{P}$ uptake of wheat plants and their association with arbuscular mycorrhizal (AM) fungi. Plant Soil 231: 105-112. 